\title{
Advanced Mucinous Adenocarcinoma Arising from a Mature Cystic Teratoma: A Case Report and Literature Review
}

\author{
Aki Miyasaka $^{a} \quad$ Tadaaki Nishikawa $^{a}$ Eito Kozawa $^{\mathrm{b}}$ Masanori Yasuda $^{c}$ \\ Keiichi Fujiwara ${ }^{a} \quad K$ Koi Hasegawa ${ }^{a}$ \\ ${ }^{a}$ Department of Gynecologic Oncology, Saitama Medical University International Medical \\ Center, Hidaka, Japan; ${ }^{b}$ Department of Diagnostic Radiology, Saitama Medical University \\ International Medical Center, Hidaka, Japan; ${ }^{C}$ Department of Pathology, Saitama Medical \\ University International Medical Center, Hidaka, Japan
}

\section{Keywords}

Mucinous adenocarcinoma $\cdot$ Mature cystic teratoma $\cdot$ Malignant transformation

\begin{abstract}
Purpose: To describe the postoperative progressive course of advanced-stage adenocarcinoma arising from a mature cystic teratoma (MCT) and review the literature regarding this disease. Methods: A 59-year-old woman visited our hospital with an abdominal mass. Laparotomy showed enlargement of the left ovary and dissemination throughout the abdominal and pelvic cavities. The diagnosis was FIGO stage IIIB adenocarcinoma arising from a MCT. We report this case in detail with a review of the literature. Results: A literature search yielded 9 cases of stage III adenocarcinoma with malignant transformation. Six of these 9 patients died within 12 months after diagnosis. Of the 8 patients who underwent postoperative chemotherapy, 3 survived for over 39 months. The review indicates that prognosis of adenocarcinoma is as poor as that for squamous cell carcinoma arising from a MCT. Conclusions: In general, as with this case, prognosis of advanced adenocarcinoma associated with a MCT is poor. However, we should be aware that not all patients are resistant to chemotherapy.
\end{abstract}




\section{Introduction}

Malignant transformation (MT) occurs in about 1-2\% of all mature cystic teratomas (MCTs) of the ovary [1-3]. Squamous cell carcinoma (SCC), which is the most common histology, accounts for 75-85\% of MCTs, while adenocarcinomas account for only about 7\% [4]. The prognosis of an advanced carcinoma associated with a MCT is worse than that of an epithelial ovarian carcinoma, mainly because chemotherapy is much less effective for the former. Although the prognosis for a stage I MCT with MT is generally good, the 2-year survival rate of patients with stage II-IV tumors is reported to be extremely poor, ranging from 0 to $30 \%$ [5]. The underlying reasons for this prognostic difference between adenocarcinoma and SCC arising from a MCT remain unclear, particularly for advanced-stage tumors, and there have been relatively few reports of advanced adenocarcinomas associated with MCTs to date. Here, we report a case of advanced mucinous adenocarcinoma arising from a MCT. We also systematically reviewed adenocarcinomas arising from MCTs to identify prognostic differences between adenocarcinoma and SCC.

\section{Case}

A 59-year-old woman (gravida 3, para 3) visited our hospital with an abdominal mass, which was suspected to be an ovarian tumor. Her past history included cystectomy and salpingo-oophorectomy for the treatment of MCTs at the age of 30 years. Magnetic resonance imaging on her first visit revealed a large ovarian tumor in her pelvis with a diameter of $>30$ $\mathrm{cm}$. The tumor was composed of multilocular cysts and fatty components (fig. 1a-d). A computed tomography (CT) scan was negative for lymphadenopathy and dissemination. Serum concentrations of cancer antigen (CA)125, CA19-9, and carcinoembryonic antigen (CEA) were $156 \mathrm{U} / \mathrm{ml}, 2,676 \mathrm{U} / \mathrm{ml}$, and $16 \mathrm{ng} / \mathrm{ml}$, respectively. The preoperative diagnosis was a malignant tumor of the ovary with a mucinous borderline or MT arising from a MCT. We observed deep vein thrombosis during her preoperative screening and thus began preoperative heparinization.

An enlarged tumor of the left ovary was confirmed at the time of laparotomy, which comprised two large cysts. One contained numerous small fat balls and hair balls, while the other contained serous fluid with microcystic components of the tumor wall. We observed small disseminations throughout the pelvis and abdomen, and the cytology of ascites was positive. An intraoperative pathological diagnosis during salpingo-oophorectomy suggested a mucinous adenocarcinoma coexisting with a MCT. Therefore, total hysterectomy and partial omentectomy were also performed. Pathological analysis showed mature skin and adipose tissue in the tumor (fig. 2b). Transition from a mucinous adenoma to a welldifferentiated mucinous adenocarcinoma was found (fig. 2a). The final pathologic diagnosis was mucinous adenocarcinoma arising from a MCT and the FIGO stage was IIIB.

She was discharged on postoperative day 9 and prescribed warfarin at a dose of $3 \mathrm{mg}$. She chose to be followed without chemotherapy. At a routine 4-month follow-up, tumor markers were elevated and a CT scan revealed subcutaneous and bone metastasis with multiple metastases in the lungs, liver, and lymph nodes. After consultation, she was referred for hospice care. She died of the disease 6 months after surgery. 


\section{Discussion}

Here, we report our experience of a very rapid progression of an advanced mucinous adenocarcinoma arising from a MCT of the ovary. An adenocarcinoma arising from a MCT is considered to be a rare gynecologic tumor. Other than surgical resection, no standard treatment has been proven successful for this type of tumor. We searched the PubMed database (http://www.ncbi.nlm.nih.gov/pubmed) for reports on adenocarcinomas associated with MCTs written in English using the key words 'adenocarcinoma', 'malignant transformation', and 'mature cystic teratoma'. This search included two reviews and 42 patients in case reports and case series. One review published in 1957 reported 15 MCT-associated cases of adenocarcinoma [1] and the other published in 1993 reported 24 cases [2]. However, only 42 cases have been reported in the English literature over the 20-year period from 1994 to 2015. Of these 42 cases, 31 (74\%) were stage I, 1 (2\%) was stage II, 9 (21\%) were stage III, and none were stage IV, while the stage for 1 case was unknown. The detailed histotypes of these adenocarcinomas were mucinous (33\%), no description (28\%), and others, including sebaceous, thyroid, sweat gland, mammary, salivary gland, prostate, clear cell, endometrioid, serous, and poorly differentiated. Cases of advanced adenocarcinomas seem to be relatively rare, with only 9 reported to date. The details of these 9 cases of advanced adenocarcinoma are summarized in table 1 . Of these 9 cases, $6(67 \%)$ were stage IIIC and none were stage IV. Cases 1 and 2 were diagnosed with lymph node metastasis without peritoneal dissemination $[6,7]$. Five cases were diagnosed as mucinous adenocarcinoma, and 3 were described as adenocarcinoma. Eight patients underwent chemotherapy after surgery, including 3 who received combination therapy of paclitaxel and carboplatin. It is generally known that the prognosis of advanced-stage MT is extremely poor, while that of stage I is fairly good. A review of SCC cases associated with MCT found that the median survival of stage II-IV was less than 12 months, and overall survivals of stage II/III and IV were 20 and $0 \%$, respectively [5]. When limited to cases of advanced adenocarcinoma, 5 (56\%) of 9 patients died of the disease within 12 months (table 1), and the overall survival rate of stage III cases was $30 \%$ (fig. 3 ). These data indicate that the prognosis of advanced-stage adenocarcinoma is as poor as that of advanced cases of SCC arising from a MCT. Eight (89\%) of 9 patients underwent postoperative chemotherapy. It is worth noting that $3(38 \%)$ of 8 stage III cases treated by cytoreductive surgery followed by adjuvant chemotherapy survived for over 39 months, which may indicate that chemotherapy is an effective treatment for some of these types of tumors. However, there currently is no established chemotherapy regimen for MT. According to a review of SCC [5], in addition to cisplatin, alkylating drugs should be considered. Regarding tumor markers, the median value of CA125 was $36 \pm 446 \mathrm{ng} / \mathrm{ml}(\mathrm{n}=13)$ for stage I and 156 $\pm 518 \mathrm{ng} / \mathrm{ml}$ for stage III $(\mathrm{n}=5)(\mathrm{p}=0.37)$, suggesting that CA125 is increased in some adenocarcinomas. However, this evidence is not conclusive that CA125 is a predictable marker of disease progression. According to available data in the literature, serum CEA levels were elevated in all patients. Only cases 2 and 3 had detailed descriptions of the clinical courses $[7,8]$. In accordance with these reports, disease progression was rapid in our case.

Reports of advanced adenocarcinomas arising from MCTs are limited; thus, it is difficult to discuss biological and clinical characteristics in this review. Nonetheless, available data suggest that these tumors have a poor prognosis, as does advanced-stage SCC, and that some patients may benefit from systemic chemotherapy. 
 Oncology}

\begin{tabular}{l|l}
\hline Case Rep Oncol 2016;9:331-337 \\
\hline $10.1159 / 000447258$ & $\begin{array}{l}\text { (c) 2016 The Author(s). Published by S. Karger AG, Basel } \\
\text { www.karger.com/cro }\end{array}$ \\
\hline
\end{tabular}

Miyasaka et al.: Advanced Mucinous Adenocarcinoma Arising from a Mature Cystic Teratoma: A Case Report and Literature Review

Statement of Ethics

The authors have no ethical conflicts to disclose.

\section{Disclosure Statement}

The authors declare that there are no conflicts of interest.

\section{References}

1 Peterson WF: Malignant degeneration of benign cystic teratomas of the overy; a collective review of the literature. Obstet Gynecol Surv 1957;12:793-830.

-2 Ueda G, Fujita M, Ogawa H, Sawada M, Inoue M, Tanizawa O: Adenocarcinoma in a benign cystic teratoma of the ovary: report of a case with a long survival period. Gynecol Oncol 1993;48:259-263.

Kushima M: Adenocarcinoma arising from mature cystic teratoma of the ovary. Pathol Int 2004;54:139-143.

4 Powell JL, Stinson JA, Connor GP, Shiro BS, Mattison M: Squamous cell carcinoma arising in a dermoid cyst of the ovary. Gynecol Oncol 2003;89:526-528.

5 Hackethal A, Brueggmann D, Bohlmann MK, Franke FE, Tinneberg HR, Munstedt K: Squamous-cell carcinoma in mature cystic teratoma of the ovary: systematic review and analysis of published data. Lancet Oncol 2008;9:1173-1180.

-6 Park JH, Whang SO, Song ES, Choi SJ, Lee WY: An ovarian mucinous cystadenocarcinoma arising from mature cystic teratoma with para-aortic lymph node metastasis: a case report. J Gynecol Oncol 2008;19:275-278.

7 Kajo K, Masak L, Sorkovska D, Vallova M, Kajo M, Machalekova K, Helpianska L: Mucinous carcinoma (non-intestinal type) arising in the ovarian mature cystic teratoma - a case report. Cesk Patol 2013;49:141-145.

8 Fishman A, Edelstein E, Altaras M, Beyth Y, Bernheim J: Adenocarcinoma arising from the gastrointestinal epithelium in benign cystic teratoma of the ovary. Gynecol Oncol 1998;70:418-420.

-9 Park JY, Kim DY, Kim JH, Kim YM, Kim YT, Nam JH: Malignant transformation of mature cystic teratoma of the ovary: experience at a single institution. Eur J Obstet Gynecol Reprod Biol 2008;141:173-178.

10 Templeman CL, Fallat ME, Lam AM, Perlman SE, Hertweck SP, O'Connor DM: Managing mature cystic teratomas of the ovary. Obstet Gynecol Surv 2000;55:738-745.

11 Yamaguchi K, Mandai M, Fukuhara K, Higuchi T, Hamanishi J, Takakura K, Fujii S: Malignant transformation of mature cystic teratoma of the ovary including three cases occurring during follow-up period. Oncol Rep 2008;19:705-711.

12 Black JD, Roque DM, Pasternak MC, Buza N, Rutherford TJ, Schwartz PE, McCarthy S, Ratner E: A series of malignant ovarian cancers arising from within a mature cystic teratoma: a single institution experience. Int J Gynecol Cancer 2015;25:792-797. 


\section{Case Reports in Oncology}

\begin{tabular}{l|l}
\hline Case Rep Oncol 2016;9:331-337 \\
\hline $10.1159 / 000447258$ & $\begin{array}{l}\text { c 2016 The Author(s). Published by S. Karger AG, Basel } \\
\text { www.karger.com/cro }\end{array}$ \\
\hline
\end{tabular}

Miyasaka et al.: Advanced Mucinous Adenocarcinoma Arising from a Mature Cystic Teratoma: A Case Report and Literature Review
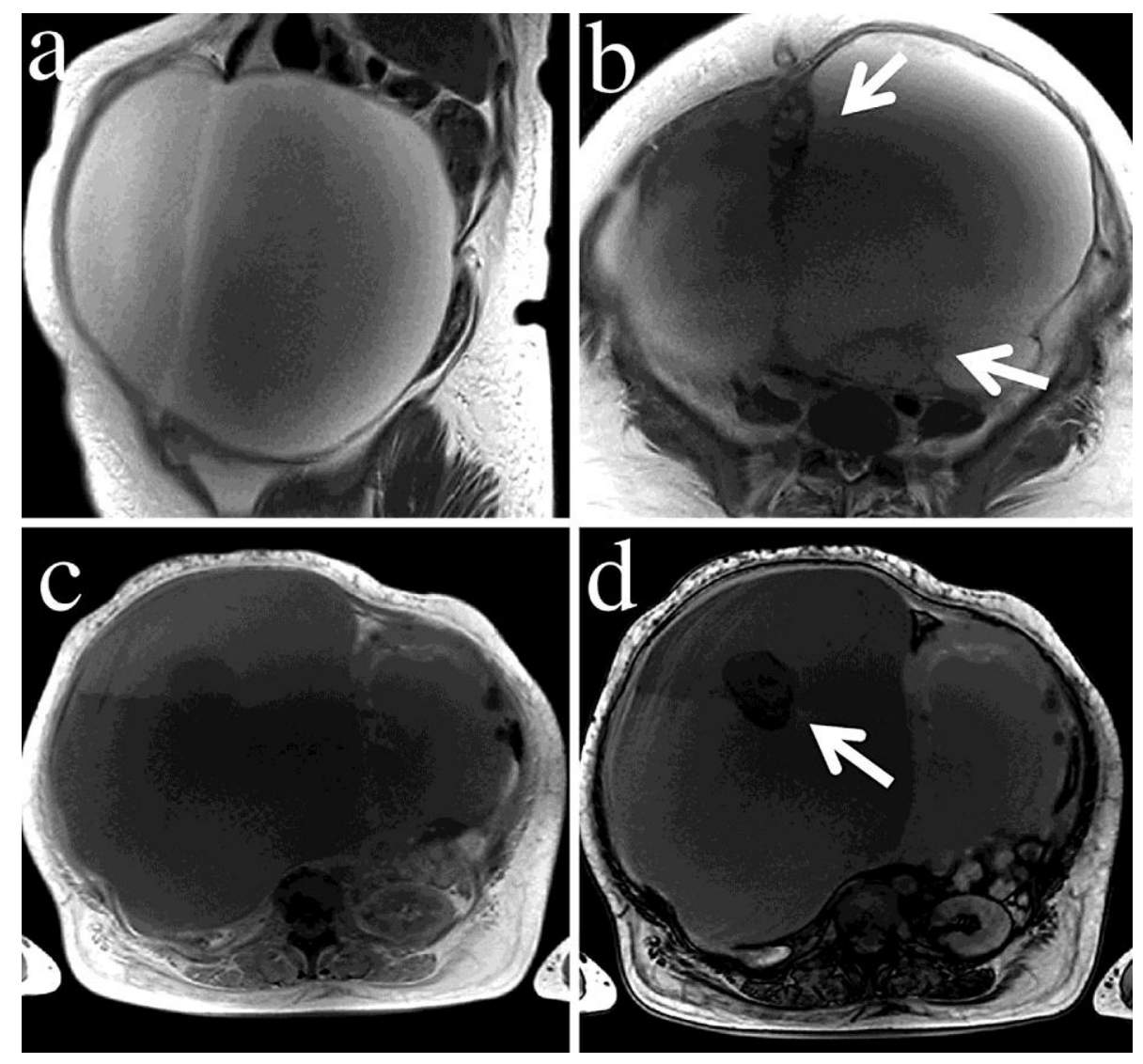

Fig. 1. a A sagittal T2-weighted image showing a large mass with fluid-fluid level in the pelvis. $\mathbf{b}$ An axial T2-weighted image showing a large mass with multiple cystic components (arrows). c An axial in-phase T1-weighted image showing a large lobulated mass with some signal intensity. $\mathbf{d}$ An axial opposed-phase T1-weighted image showing partial signal loss, as compared to the in-phase T1-weighted image in the central nodule (arrow). This finding indicates that the lesion contains fat and water in the same voxel. 


\section{Case Reports in Oncology}

\begin{tabular}{l|l}
\hline Case Rep Oncol 2016;9:331-337 \\
\hline $10.1159 / 000447258$ & $\begin{array}{l}\text { (c) 2016 The Author(s). Published by S. Karger AG, Basel } \\
\text { www.karger.com/cro }\end{array}$ \\
\hline
\end{tabular}

Miyasaka et al.: Advanced Mucinous Adenocarcinoma Arising from a Mature Cystic Teratoma: A Case Report and Literature Review
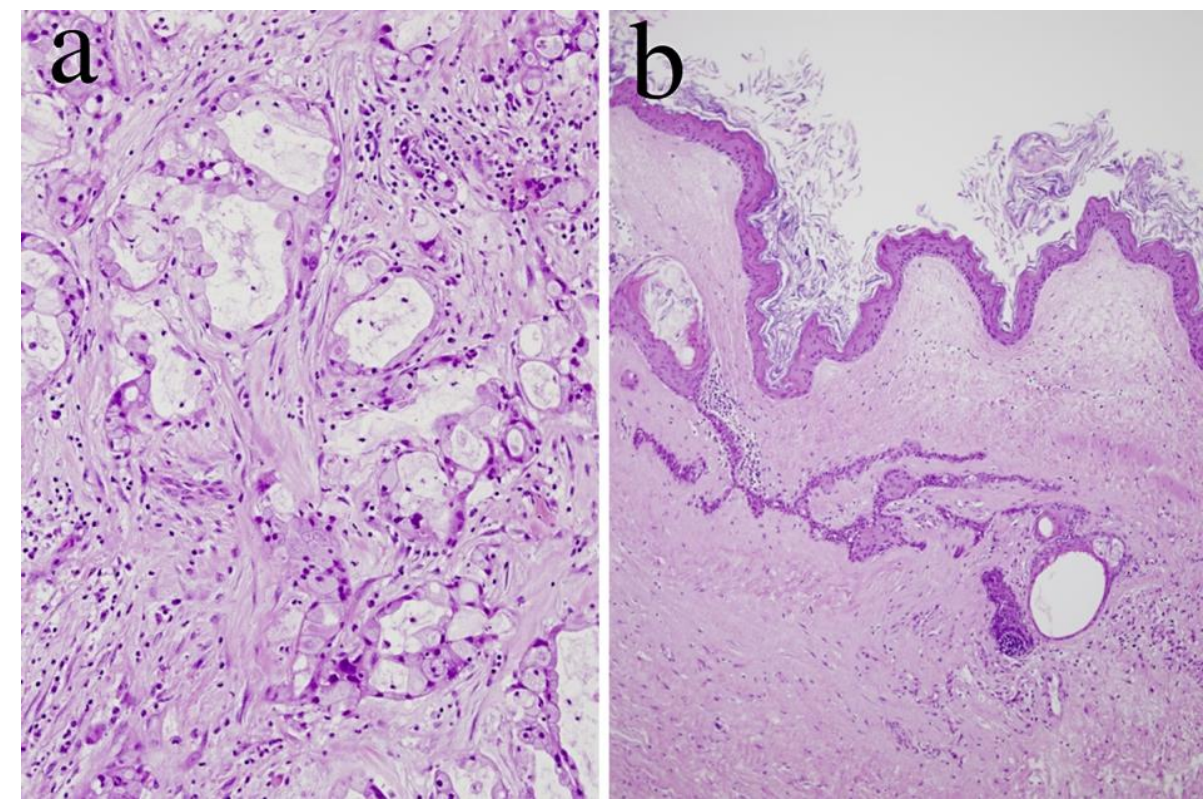

Fig. 2. a Atypical mucin-containing epithelial cells arranged in a tubular conformation invading the stroma. H\&E staining. $\times 100$. b Mature squamous epithelial cells and skin appendages in the background. H\&E staining. $\times 40$.

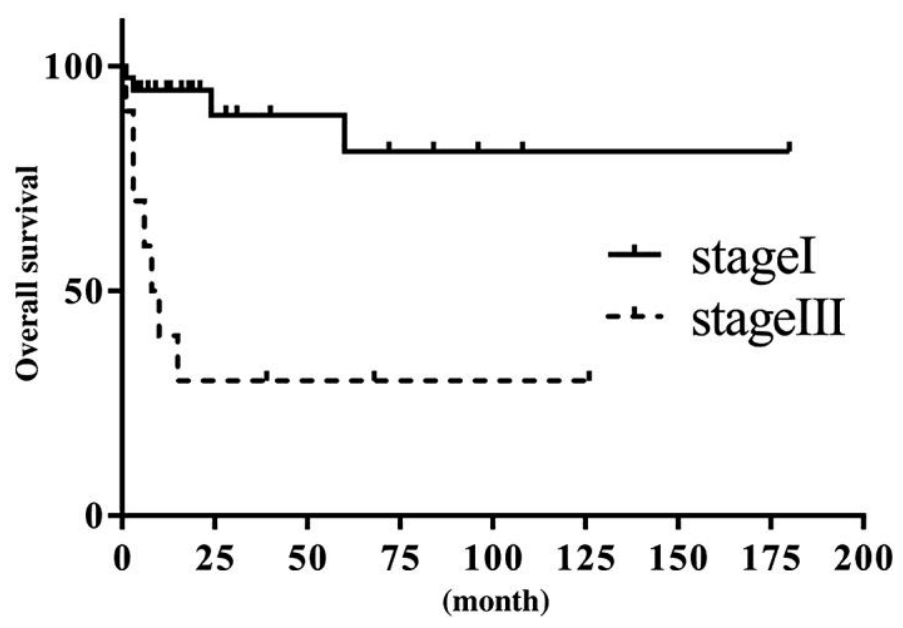

Fig. 3. Kaplan-Meier survival curve of stage I and III adenocarcinomas. The overall survival rates for stage I and III were about 75 and $30 \%$, respectively. The median survival of stage III was less than 12 months. 
Miyasaka et al.: Advanced Mucinous Adenocarcinoma Arising from a Mature Cystic Teratoma: A Case Report and Literature Review

Table 1. Advanced-stage adenocarcinomas arising from MCTs

\begin{tabular}{|c|c|c|c|c|c|c|c|c|c|c|}
\hline \multirow[t]{2}{*}{ Case } & \multirow{2}{*}{$\begin{array}{l}\text { Authors } \\
\text { [Ref.], year }\end{array}$} & \multirow{2}{*}{$\begin{array}{l}\text { Age, } \\
\text { years }\end{array}$} & \multirow{2}{*}{$\begin{array}{l}\text { FIGO } \\
\text { stage }\end{array}$} & \multicolumn{2}{|c|}{ Tumor marker } & \multirow[t]{2}{*}{ Histology } & \multirow{2}{*}{$\begin{array}{l}\text { Surgical } \\
\text { procedure }\end{array}$} & \multirow{2}{*}{$\begin{array}{l}\text { Adjuvant } \\
\text { therapy }\end{array}$} & \multirow{2}{*}{$\begin{array}{l}\text { Last } \\
\text { status }\end{array}$} & \multirow{2}{*}{$\begin{array}{l}\text { F/U after } \\
\text { operation } \\
\text { (months) }\end{array}$} \\
\hline & & & & CA125 & CEA & & & & & \\
\hline 1 & $\begin{array}{l}\text { Park et al. } \\
{[6], 2008}\end{array}$ & 41 & $3 \mathrm{~A}$ & 45 & 41.8 & mucinous & $\begin{array}{l}\text { TAH, BSO, OMT, } \\
\text { PLND, PALND, Appe }\end{array}$ & & & \\
\hline 2 & $\begin{array}{l}\text { Kajo et al. } \\
{[7], 2013}\end{array}$ & 38 & $3 \mathrm{~A}$ & 550 & 32.9 & mucinous & $\begin{array}{l}\text { TAH, BSO, OMT, } \\
\text { PLND, PALND }\end{array}$ & TCG $\times 9$ & alive & 39 \\
\hline 3 & $\begin{array}{l}\text { Fishman et al. } \\
{[8], 1998}\end{array}$ & 38 & $3 \mathrm{C}$ & 80 & 40 & adeno & $\begin{array}{l}\text { TAH, BSO, OMT, } \\
\text { Appe }\end{array}$ & $\mathrm{TC} \times 6$ & DOD & 15 \\
\hline$\overline{4}$ & $\begin{array}{l}\text { Park et al. } \\
{[9], 2008}\end{array}$ & 71 & $3 \mathrm{C}$ & - & - & adeno & $\begin{array}{l}\text { BSO, OMT, PLND, } \\
\text { Appe }\end{array}$ & $\begin{array}{l}5 \mathrm{FU}, \\
\text { leucovorin }\end{array}$ & DOD & 3 \\
\hline 5 & $\begin{array}{l}\text { Park et al. } \\
{[9,10], 2008}\end{array}$ & 44 & $3 \mathrm{C}$ & - & - & adeno & TAH, BSO, TO & $\mathrm{TC} \times 9$ & DOD & 8 \\
\hline 6 & $\begin{array}{l}\text { Yamaguchi et } \\
\text { al. [11], } 2008\end{array}$ & 48 & $3 \mathrm{C}$ & 1,276 & 12.3 & clear cell & $\begin{array}{l}\text { Supra-TAH, } \\
\text { BSO, OMT }\end{array}$ & $\mathrm{CAP} \times 8$ & alive & 126 \\
\hline 7 & $\begin{array}{l}\text { Black et al. } \\
{[12], 2015}\end{array}$ & 65 & $3 \mathrm{C}$ & - & - & mucinous & $\begin{array}{l}\text { TAH, BSO, OMT, } \\
\text { PLND, PALND, Appe }\end{array}$ & IP & DOD & 10 \\
\hline 8 & $\begin{array}{l}\text { Black et al. } \\
{[12], 2015}\end{array}$ & 58 & $3 \mathrm{C}$ & - & - & mucinous & TAH, BSO, OMT & FOLFOX $\times 10$ & alive & 68 \\
\hline 9 & $\begin{array}{l}\text { Present } \\
\text { case, } 2016\end{array}$ & 59 & $3 B$ & 156 & 16 & mucinous & TAH, BSO, OMT & $\begin{array}{l}\text { GEMOX } \times 1 \\
\text { none }\end{array}$ & $\begin{array}{l}\text { DOD } \\
\text { DOD }\end{array}$ & $\begin{array}{l}1 \\
6\end{array}$ \\
\hline
\end{tabular}

$\mathrm{TAH}$ = Total abdominal hysterectomy; $\mathrm{BSO}=$ bilateral salpingo-oophorectomy; $\mathrm{R}(\mathrm{L}) \mathrm{SO}$ = right (left) salpingo-oophorectomy; OMT = omentectomy; PLN = pelvic lymphadenectomy; $\mathrm{PAN}=$ para-aortic lymphadenectomy; Appe = appendectomy; TC = taxol and carboplatin; $\mathrm{TCG}$ = taxol, carboplatin, and gemcitabine; $\mathrm{CAP}$ = cyclophosphamide, adriamycin, and cisplatin; 5FU = 5-fluorouracil; IP = intraperitoneal chemotherapy; FOLFOX = 5-fluorouracil, leucovorin, and oxaliplatin; GEMOX = gemcitabine and oxaliplatin; DOD = died of disease. 